\title{
MANGANESE UPTAKE AND REDISTRIBUTION IN SOYBEAN AS AFFECTED BY GLYPHOSATE ${ }^{(1)}$
}

\author{
Ciro Antonio Rosolem ${ }^{(2)}$, Gabriel José Massoni de Andrade ${ }^{(3)}$, Izaias \\ Pinheiro Lisboa ${ }^{(4)} \&$ Samuel Menegatti Zoca ${ }^{(4)}$
}

\begin{abstract}
SUMMARY
Detrimental effects of glyphosate on plant mineral nutrition have been reported in the literature, particularly on Mn uptake and redistribution. However, in most of the experiments conducted so far glyphosate-susceptible plants were used. Effects of glyphosate on Mn absorption kinetics, accumulation, and distribution within the plant, as well as soybean response to Mn as affected by glyphosate were studied in three experiments. In the first experiment, in nutrient solution, the effect of glyphosate on soybean Mn uptake kinetic parameters (Imax, $\mathrm{Km}$ and $\mathrm{Cmin}$ ) was determined. In a second experiment, also in nutrient solution, differential Mn accumulation and distribution were studied for a conventional soybean cultivar and its near-isogenic glyphosate-resistant counterpart as affected by glyphosate. In a third experiment, response of glyphosate-resistant soybean cultivars to Mn application was studied in the presence of glyphosate, in pots with Mn-deficient soil. Maximum Mn influx (Imax) was higher in the herbicide-resistant (GR) cultivar than in its conventional counterpart. Glyphosate applied to nutrient solution at low rates decreased $\mathrm{Km}$ and $\mathrm{Cmin}$. A few days after herbicide treatment, RR soybean plants developed yellowish leaves, a symptom which, in the field, could be misinterpreted as Mn deficiency, but herbicide application had no effect on Mn uptake or distribution within the plant. In the soil experiment, soybean Mn uptake was increased by Mn application, with no effect of glyphosate. Under greenhouse conditions, there was no evidence of deleterious effects of glyphosate on Mn absorption, accumulation and distribution in the plant and on soybean cultivars response to Mn application.
\end{abstract}

Index terms: absorption kinetics, micronutrient, mineral nutrition.

\footnotetext{
(1) Received for publication in March 2010 and approved in October 2010.

(2) Professor Titular do Departamento de Produção Vegetal, Universidade Estadual Paulista - UNESP. Caixa Postal 237, CEP 18603970 Botucatu (SP). Bolsista do CNPq. E-mail: rosolem@fca.unesp.br

(3) Mestre, Departamento de Produção Vegetal, UNESP. E-mail: gandrade@fca.unesp.br

(4) Mestrando, Departamento de Produção Vegetal, UNESP. E-mail: samuelzoca@yahoo.com.br
} 


\title{
RESUMO: ABSORÇÃO E REDISTRIBUIÇÃO DO MANGANÊS EM SOJA TRATADA COM GLIFOSATE
}

\begin{abstract}
Efeitos negativos do glifosate na nutrição mineral da soja têm sido relatados, particularmente na absorção e redistribuição do $\mathrm{Mn}$, mas a maioria dos experimentos da literatura foi conduzida utilizando-se plantas não resistentes ao herbicida. Os efeitos do glifosate na cinética de absorção, acumulação e distribuição do Mn em soja foram estudados em três experimentos. No primeiro, em solução nutritiva, os parâmetros de absorção de $\mathrm{Mn}$ (Imax, Km e Cmin) foram determinados em função da aplicação de glifosate. Em um segundo experimento, a absorção e a distribuição diferencial do Mn na soja foram determinadas, em solução nutritiva, em função da aplicação de glifosate, empregando-se uma variedade convencional e sua quase-isogênica resistente ao herbicida (RR). No terceiro experimento, foi estudada a resposta de variedades de soja resistentes ao glifosate ao Mn aplicado na presença e ausência do herbicida, em vasos com solo deficiente em Mn. O influxo máximo (Imax) foi maior na variedade RR que na convencional. O herbicida aplicado à solução nutritiva em baixas doses diminuiu o Km e o Cmin. Alguns dias após a aplicação do glifosate, a soja desenvolveu amarelecimento nas folhas, um sintoma que, no campo, poderia ser interpretado como deficiência de $\mathrm{Mn}$, porém no tratamento com herbicida não houve efeito na absorção ou distribuição desse elemento na planta. No experimento com solo, a absorção de Mn pela soja foi aumentada com a aplicação de $\mathrm{Mn}$, sem efeito do herbicida. Em condições controladas, não foram encontradas evidências de efeitos negativos do glifosate na absorção, acumulação, distribuição do Mn na soja e na resposta da planta a esse elemento.
\end{abstract}

Termos de indexação: cinética de absorção, micronutriente, nutrição mineral.

\section{INTRODUCTION}

Glyphosate has been shown to interfere with soybean mineral nutrition, affecting the uptake and/ or redistribution of $\mathrm{Mn}$ and other nutrients (Ozturk et al., 2009; Zobiole et al., 2010). In Brazil, both Mn toxicity and deficiency have been reported as a problem, depending on the region (Rosolem et al., 2004).

Manganese is an important co-factor for several enzymes associated with the shikimic acid pathway, including phenolic aromatic amino acids, coumarins, lignins and flavonoids. A light Mn deficiency decreases photosynthesis and soluble carbohydrate levels in the plant, while a severe deficiency causes irreversible breakdown of chloroplast structure (Marschner, 1995). When subjected to Mn deficiency, soybean plants develop interveinal chlorosis in young leaves. Deficiency in soybean has been associated with leaf Mn levels reach between 10 and $20 \mathrm{mg} \mathrm{kg}^{-1} \mathrm{Mn}$ (Malavolta et al., 2000). Since the nutrient mobility in the phloem is very limited when Mn availability is high, the highest amount of the nutrient is usually found in the roots (Rosolem, 1989).

The herbicide glyphosate is absorbed and translocated in the phloem to plant roots and rhizomes. It inhibits the activity of the enzyme enolpyruvyl shikimate-3-phosphate synthase (EPSP), preventing the synthesis of aromatic amino acids which are precursors of substances such as alkaloids, flavonoids and lignin (Amarante Jr. et al., 2002). In the case of glyphosate-resistant soybean, resistance was achieved by the insertion of a gene from the Agrobacterium sp. genome, which encodes a variant of EPSPS (CP4 EPSPS), especially resistant to inhibition by glyphosate. Glyphosate decreases leaf and hypocotyl chlorophyll contents (Hoagland, 1980), even in glyphosate-resistant (GR) cultivars (Reddy et al., 2004), a symptom that could also be attributed to Mn deficiency (Malavolta, 1997). Chlorophyll is highly sensitive to glyphosate because the synthesis of its precursor, the $\delta$-aminolevulinic acid is strongly inhibited (Cole, 1985), which leads to a characteristic chlorotic growth of plants exposed to sub-lethal doses of the herbicide (Wong, 2002).

Glyphosate can be exuded by the target plant roots, released in small amounts in the rhizosphere and be absorbed, at least in part, by non-target plants (Kremer et al., 2005). A glyphosate-resistant soybean plant may exude 1,500 ng of glyphosate in the rhizosphere in 16 days (Kremer et al., 2005). Herbicide activity in non-target plants was found to be around $1.0 \%$ in roots and $0.08 \%$ in shoots, compared with the target plant (Ricordi et al., 2007). This amount transferred through the rhizosphere should not be enough to cause damage to non-target plants. However, low rates of the herbicide (around $2 \%$ of the normally recommended dose) applied to leaves of non-transgenic soybean plants decreased the absorption and translocation of Mn (Römheld et al., 2005).

Although glyphosate is effective in controlling weeds, there are reports of various physiological side effects. Among these side effects a decrease in Mn absorption and translocation in soybean has been 
reported (Römheld et al., 2005, Orzturk et al., 2008). Since most of these effects were observed in glyphosatesusceptible plants, it is unclear whether this effect also occurs in glyphosate-resistant (GR) plants. Zobiole et al. (2010) concluded that fertilizer recommendations for GR crops should consider the reduced nutrient efficiency imposed by the presence of the GR gene as well as the further impact of glyphosate on nutrient use. The problem is that the nutrient use efficiency was not determined in that experiment. Nutrient leaf concentrations, including Mn, were decreased in GR soybean both by the gene and glyphosate application, but the effect was not generalized across soybean maturity groups and soils (Zobiole et al., 2010). However, in this particular experiment, Mn levels in the leaves were very high and, therefore, the decrease in dry matter yields can not be attributed to nutrient deficiencies.

A decrease in nutrient uptake and/or use by plants may result from a deficiency in the nutrient media, from a deleterious effect on the nutrient absorption kinetics or from an impairment of nutrient redistribution within the plant. In this study we analyzed Mn uptake kinetics in two near-isogenic soybean cultivars as affected by low glyphosate rates in the nutrient solution. Furthermore, Mn uptake and translocation in GR soybean cultivars and response to Mn after glyphosate application were also studied.

\section{MATERIAL AND METHODS}

Three experiments were carried out to study: (a) the kinetics of Mn absorption as affected by glyphosate applied to the nutrient solution; (b) the comparative Mn uptake and distribution of near-isogenic soybean cultivars, and (c) the response to $\mathrm{Mn}$ in glyphosatetreated soybean grown on a Mn-deficient soil.

For the first experiment, two near-isogenic soybean cultivars, Conquista and Valiosa, were grown in nutrient solution to study absorption kinetics. Valiosa RR (GR) was derived from the cross of cv. Conquista with a genotype carrying the glyphosate-resistance gene. After five retro- crosses, it was estimated that cv. Valiosa RR possesses about $98.4 \%$ of Conquista genes. Seeds were germinated in paper towels moistened with $0.01 \mathrm{~mol} \mathrm{~L}^{-1} \mathrm{CaSO}_{4}$. After one week they were selected for uniformity and transferred to two-liter pots with $10 \%$ strength Hoagland solution. In the second week the solution was changed to $1 / 2$ strength and in the third week to full strength. Two plants were grown per pot. Solution $\mathrm{pH}$ was monitored and maintained at around 5.5 using $\mathrm{HCl}$ or $\mathrm{NaOH}$. The temperature in the greenhouse was kept at $30{ }^{\circ} \mathrm{C} \pm 5$. Three weeks after plant emergence (V4) the parameters defining Mn absorption kinetics were determined using the solution depletion technique (Claassen et al., 1974). The plant root system was washed with distilled water and left $24 \mathrm{~h}$ in a Mn-free solution. Then, the plants were transferred to a Mn solution with $14.5 \mu \mathrm{M} \mathrm{L}^{-1}$ and left to equilibrate for $2 \mathrm{~h}$ (Epstein \& Hagen, 1952). After this, the solution was changed again, with the same nutrient concentrations, and Glyphosate was applied to the nutrient solution (to mimic a rhizosphere transfer) at rates of $0,8,16,32,64$ and $128 \mu \mathrm{g} \mathrm{L}^{-1}$ ) a.e. (acid equivalent). Solution samples of $5 \mathrm{~mL}$ were taken to analyze Mn 30, 45, 60, 75, 120, 210, 390, 750, and 1,470 min after herbicide application. At the end of this depletion period, plants were collected and divided into shoots and roots, dried in a forced-air oven at $65^{\circ} \mathrm{C}$ for $72 \mathrm{~h}$ and weighed. The experiment had a $2 \times 6$ factorial design in randomized blocks with four replications. After ANOVA, the means were compared using LSD $(\mathrm{p}<0.05)$

In the second experiment, Mn uptake and distribution were studied. The same soybean cultivars were used and also grown in nutrient solution. Plants were obtained as described above. The transgenic cultivar Valiosa (treated or not with glyphosate) and the conventional cultivar Conquista were grown in the presence of 1.0, 2.0, 4.0, 6.0, 10.0, and $20.0 \mu \mathrm{mol} \mathrm{L}^{-1} \mathrm{Mn}$ in the nutrient solution. Glyphosate (360 $\mathrm{g} \mathrm{L}^{-1}$ active ingredient) was sprayed at a rate of $540 \mathrm{~g} \mathrm{ha}^{-1}$ (a.e.) in the respective treatments 25 days (V4) after plant emergence. Plants were placed in rows $0.45 \mathrm{~m}$ apart (as they would be in the field) outside the greenhouse for herbicide application, to mimic field conditions. Plants were sprayed at 8:00 h AM using a backpack sprayer with SF 110.02 nozzles at a constant pressure of $2 \mathrm{kgf} \mathrm{cm}^{-2}$ and $200 \mathrm{~L} \mathrm{ha}^{-1}$. The pots were closed tightly to avoid solution contamination.

The experiment was harvested 40 days after plant emergence (V 8). The plants were divided into roots, stems and leaves, washed in distilled water and dried in a forced-air oven at $65^{\circ} \mathrm{C}$ for $72 \mathrm{~h}$. In order to determine Mn uptake and distribution within the plant, the material was ground, wet-acid digested and Mn was determined in each plant part by atomic absorption spectroscopy as described by Malavolta et al. (1997).

The experiment was arranged in a $6 \times 3$ factorial design in complete randomized blocks with four replications. The results were subjected to ANOVA and means were compared using LSD $(p<0.05)$. For $\mathrm{Mn}$ accumulation and Mn leaf concentrations regressions were fit.

The third experiment was conducted in 6 -L soil pots, in a greenhouse, using three transgenic (GR) soybean cultivars (M-SOY 7908 RR, Valiosa RR and Coodetec $226 \mathrm{RR}$ ) that were treated or not with glyphosate. The soil was a dystrophic Hapludox (sandy loam) with low $\mathrm{Mn}$ content $\left(0.7 \mathrm{mg} \mathrm{dm}^{-3}\right.$, extracted with EDTA), thus a response could be expected. Dolomitic limestone was applied to raise soil base-saturation to $60 \%$. Phosphorus and K were applied at rates of 150 and $100 \mathrm{mg} \mathrm{kg}^{-1}$, respectively, and $\mathrm{Zn}$ at $5 \mathrm{mg} \mathrm{kg}^{-1}$. The seeds were inoculated with 
Bradyrhizobium, treated with Mo and fungicide. Treatments consisted of Mn rates of $0,3.0,6.0$, $12 \mathrm{mg} \mathrm{kg}^{-1}$ and two plants were grown per pot. At the growth stage V3, glyphosate was sprayed on the plants of the respective treatments at $720 \mathrm{~g} \mathrm{ha}^{-1}$ (a.e.), arranging the plants and spray conditions as in the previous experiment. The soil surface was protected with a plastic sheet to avoid herbicide contamination. Fifteen days after herbicide application (V7), plants were harvested and divided into root and shoot, washed in distilled water, dried in a forced-air oven at $65^{\circ} \mathrm{C}$ for $72 \mathrm{~h}$. The most recently matured leaf (third from the top) was sampled for foliar diagnosis. Biomass and the Mn content in the plant tissue were determined as described in the previous experiment. The experimental design was a $3 \times 2 \times 4$ factorial in complete randomized blocks with four replications. The results were subjected to ANOVA and means compared using LSD ( $p<0.05)$. Regressions were fit to soybean dry matter and $\mathrm{Mn}$ accumulation.

\section{RESULTS}

\section{First experiment: absorption kinetics}

The maximum Mn influx (Imax) was higher in Valiosa RR than in Conquista (Figure 1). The lowest glyphosate rate $\left(8 \mathrm{mg} \mathrm{L}^{-1}\right)$ increased Imax of both cultivars when compared with plants without herbicide, which was decreased with further increases in glyphosate rates in the nutrient solution. The affinity of the uptake system for Mn ions was increased in the presence of glyphosate in the nutrient solution, because there was a decrease of $\mathrm{Km}$ with glyphosate rates (Figure 1). For Cmin (the minimum $\mathrm{Mn}$ concentration in the nutrient solution at which net uptake occurs), a significant decrease was observed at the highest glyphosate rate (results not shown).

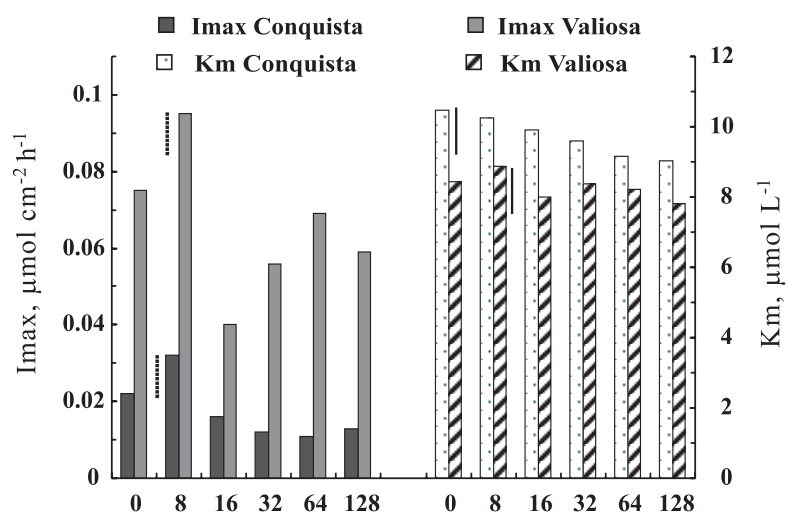

GLYPHOSATE IN NUTRIENT SOLUTION, $\mathrm{mg} \mathrm{L}^{-1}$

Figure 1. Imax and $\mathrm{Km}$ for a transgenic and a conventional soybean cultivar as affected by glyphosate rates applied to the nutrient solution. Vertical bars show LSD $(p<0.05)$, solid line Km, dashed line - Imax.

\section{Second experiment: Mn uptake and distribution}

Soybean dry matter production was similar between cultivars and there was no response either to Mn or glyphosate applied (results not shown). Within 10 to 15 days after plant emergence, some plants of both cultivars showed Mn deficiency symptoms in treatments with the lowest Mn level in nutrient solution. However, new growth was normal. Furthermore, plants sprayed with glyphosate showed, a few days after application, symptoms similar to those of Mn deficiency, which also disappeared almost completely by the time the plants were harvested. This phytotoxicity of glyphosate was also observed under field conditions in the Center-West of Brazil (Broch \& Ranno, 2008), with no effect on soybean Mn nutrition or yields. It has been reported that glyphosate may interfere with soybean response to Mn (Gordon, 2007). However, in this experiment the onset of Mn deficiency symptoms was not related to the herbicide application, which did not interfere with the Mn nutrition of soybean.

Soybean dry matter yields were not affected by Mn rates (results not shown), but Mn concentrations in soybean leaves responded to the nutrient levels in solution, resulting in higher accumulation (Figure 2). Total Mn accumulation by Conquista increased linearly with $\mathrm{Mn}$ rates in the nutrient solution (Figure 2), however, for Valiosa RR, the near-isogenic cultivar, the accumulation was quadratic. For the GR cultivar, glyphosate had no effect on plant development and dry matter production, regardless of the state of Mn nutrition. Leaf Mn concentrations
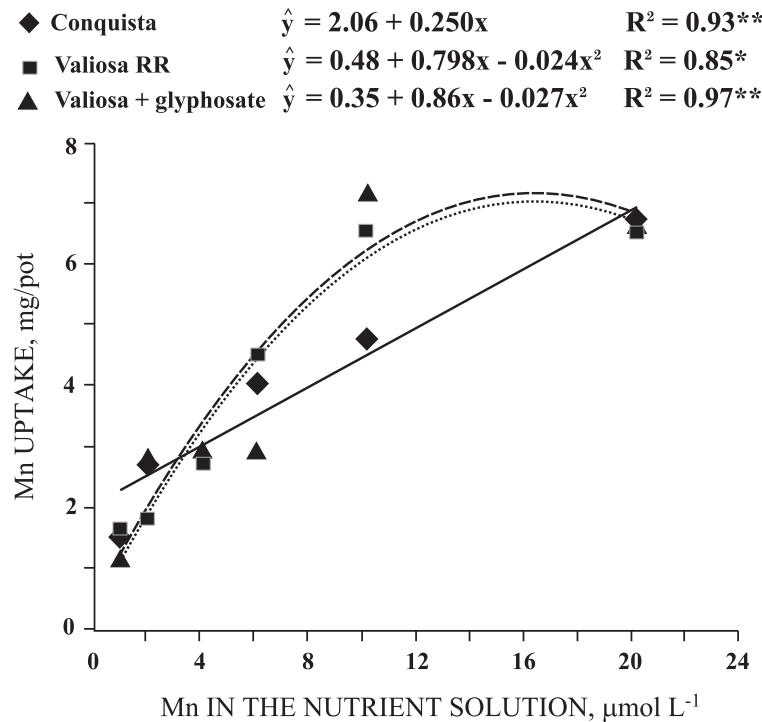

Figure 2. Manganese accumulation by soybean cultivars as affected by Mn levels in the nutrient solution and glyphosate sprayed on the glyphosate-resistant cultivar. Results were averaged across glyphosate treatments since the effect was not significant. *, ** ...significant ( $p<0.05$ and $p<0.01$, respectively). 
were lower in Valiosa when grown in the most Mndeficient solution, irrespective of the presence of the GR gene. This lower Mn concentration did however not result in lower dry matter production because even at this lowest Mn solution level, leaf Mn concentrations in all treatments were over $20 \mathrm{mg} \mathrm{kg}^{-1}$, which is considered the threshold for soybean development and production (Malavolta et al., 1997).

Manganese relative partitioning in soybean roots and shoots was not affected by herbicide application (Figure 3). However, as Mn rates increased in the nutrient solution soybean roots accumulated more $\mathrm{Mn}$ than shoots.

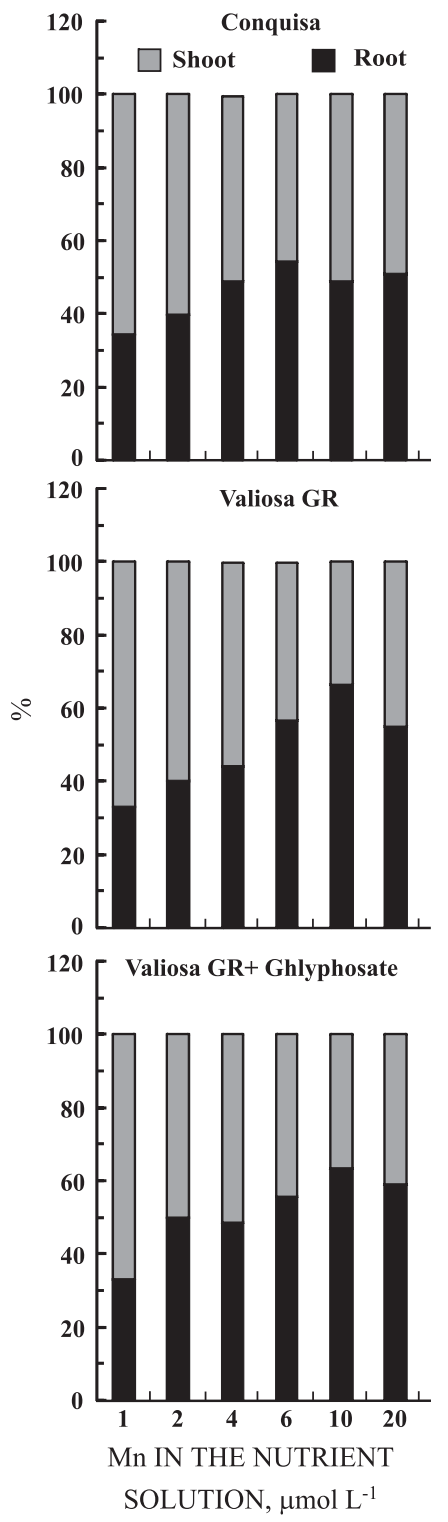

Figure 3. Manganese partitioning in soybean cultivars as affected by Mn levels in the nutrient solution and glyphosate application to a RR cultivar. Results were averaged across glyphosate treatments since the effect was not significant.

\section{Third experiment: soil}

In the soil experiment, Mn leaf concentrations at V7 (most recently matured leaf) were increased with the applied Mn rates (Figure 4), but there was no effect of glyphosate application. Monsoy 7908 accumulated more $\mathrm{Mn}$, but differences among cultivars were small. In spite of the originally low soil Mn content, liming and wet incubation must have favored organic matter mineralization, increasing Mn availability. Therefore, soybean dry matter yield did not respond to Mn application. Glyphosate application had no effect on soybean growth, Mn accumulation (Figure 5) and distribution within the plants (Figure 4) as reported earlier in a field experiment (Gordon, 2007).

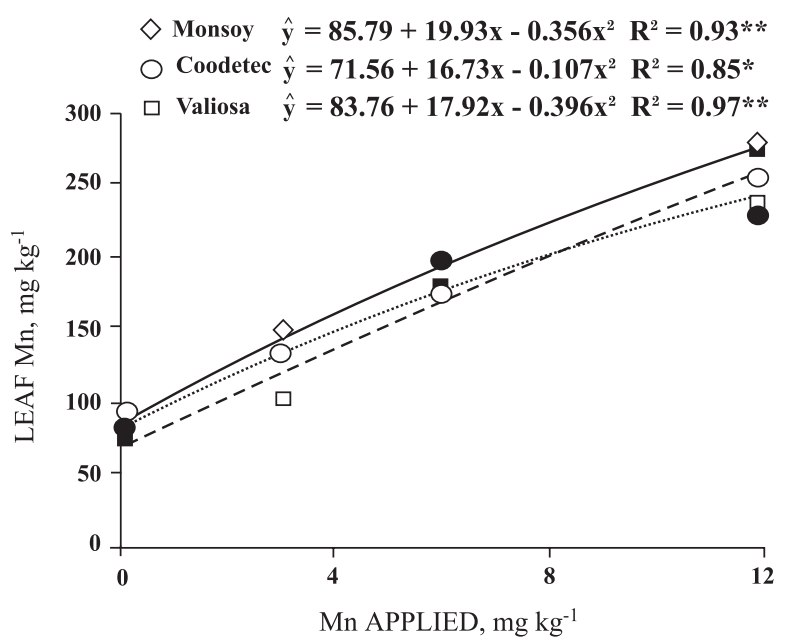

Figure 4. Manganese in soybean leaves (most recently matured leaf from the top, at V7) as affected by $\mathrm{Mn}$ rates and glyphosate. Open symbols - without glyphosate, and solid symbols - with glyphosate, for each cultivar. Lines represent the average between treatments with and without glyphosate since the effect was not significant. **... significant $(p<0.01)$.

\section{DISCUSSION}

Glyphosate did not decrease Mn concentrations in the present experiment. Since glyphosate can complex metallic cations, it could be a reason for the decreased Mn levels, as observed in soybean tissues in glyphosate-applied GR soybean (Zobiole et al., 2010). However, if Mn was complexed by glyphosate in soybean, this would be expected to occur in the actively growing plant parts, where glyphosate accumulates (Schulz et al., 1990), and certainly it would not be significant on a whole tissue basis or for the Mn concentration in the third leaf sampled at V7 in this experiment. Furthermore, Bott et al. (2008) found no indications for internal immobilization of micronutrients by excessive complexation with glyphosate. 


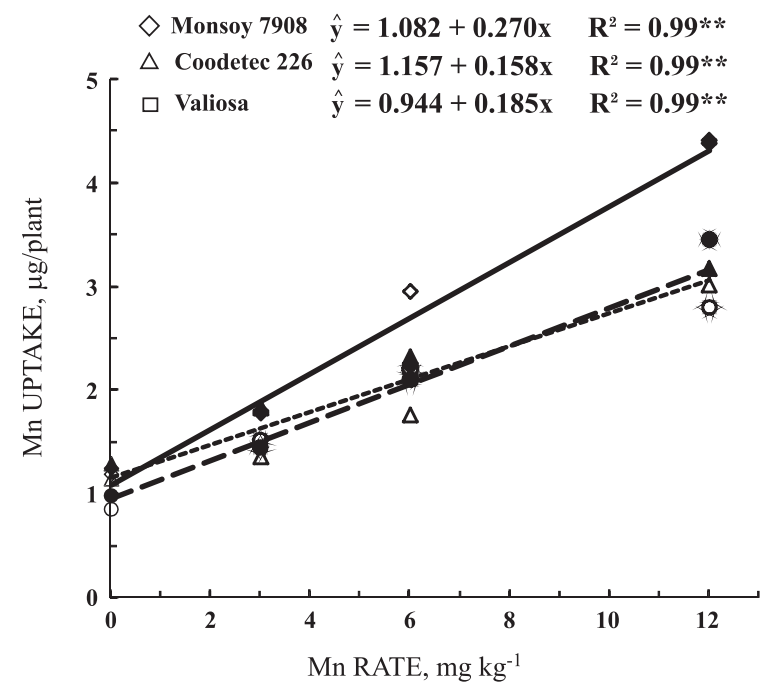

Figure 5. Manganese uptake by glyphosate-resistant soybean cultivars as affected by Mn rates applied to a Mn-deficient soil. Open symbols: with glyphosate, solid symbols: without glyphosate. There were no significant differences between glyphosate treatments. $* *$... significant $(\mathrm{p}<0.01)$.

The decrease in Imax observed in this experiment could be a result of $\mathrm{Mn}$ sequestration at the root surface level, because herbicide rates applied to the nutrient solution were higher than what would be expected in the field (Kremer et al., 2005). However, in spite of the decrease in Mn maximum influx with higher glyphosate doses, the effects on $\mathrm{Km}$ and $\mathrm{Cmin}$ suggest a higher affinity of the Mn uptake system in the presence of the herbicide, which would favor Mn absorption in soils with low Mn availability. A significant decrease in macro and micronutrients in soybean leaf tissue from different cultivar maturity groups grown on different soil types was reported (Zobiole et al., 2010). Very low glyphosate rates reduced Mn root uptake in non-GR sunflower (Ozturk et al., 2008), but our results suggest that the amount of glyphosate that could be exuded in the rizosphere of non-GR soybean in field situations would not be enough to decrease Mn uptake. Furthermore, if soybean Mn leaf concentrations may be decreased by glyphosate, this effect is not a result of an impairment of soybean Mn uptake kinetics.

When low rates of glyphosate were applied to leaves of non-transgenic soybean plants the absorption and translocation of Mn were decreased (Römheld et al., 2005) and it has been reported that glyphosate reduces the uptake, translocation, or availability of nutrients even in GR soybean (Bott et al., 2008; Zobiole, 2010), compared with the near-isogenic counterpart. In our experiment, a decrease in soybean Mn accumulation was only observed at the lowest Mn solution level (Figure 2), independently of the cultivar or glyphosate application.
For glyphosate non-resistant genotypes, a decrease in Mn uptake and translocation to the shoots has been reported (Römheld et al., 2005). Comparing Conquista and Valiosa, Bott et al. (2008) observed an inexplicable increase in Mn concentrations in young shoots of Valiosa without glyphosate, but after herbicide application this effect disappeared and Mn concentrations in Conquista without herbicide and Valiosa with glyphosate were similar. Interestingly, the increase in Mn concentration was only observed at the highest Mn concentration of that study in the nutrient solution $\left(0.5 \mu \mathrm{mol} \mathrm{L}^{-1}\right)$, which is lower than our lowest concentration $\left(1.0 \mu \mathrm{mol} \mathrm{L}^{-1}\right)$, where an incipient Mn deficiency was observed. Expression of glyphosate toxicity in GR soybean cultivars has been attributed to differences in plant physiological status, genotype, and environmental factors with impact on glyphosate turn-over (Reddy et al., 2004). Temperature plays an important role in Mn turnover in soybean (Rosolem, 1989). At low temperatures soybean requires less Mn, which can explain why observed no Mn deficiency in plants grown at temperatures between 24 and $26{ }^{\circ} \mathrm{C}$, much lower than usual in tropical environments. Furthermore, Bott et al. (2008) admitted that their findings suggest that the observed effects were a consequence rather than the cause of impaired plant growth induced by glyphosate application. However, from the present experiment it is clear that there was no interference of glyphosate with total Mn accumulation or relative distribution in the genetically modified genotypes. Mn accumulation in soybean roots may be a plant defense preventing Mn toxicity. At high availability, soybean accumulates $\mathrm{Mn}$ in cell root vacuoles to avoid translocation to shoots and the development of toxicity symptoms (Rosolem, 1989).

It has been suggested that conventional cultivars (non-GR) may have lower critical nutrient levels for physiological sufficiency than GR soybean, and fertilizer recommendations for GR crops should consider the reduced nutrient efficiency induced by the presence of the GR gene as well as the further impact of glyphosate on nutrient efficiency (Zobiole et al., 2010). In the present experiment the effect of glyphosate on Mn concentration in soybean leaves at V7 was not significant, and there was no differential response to the $\mathrm{Mn}$ applied either to the nutrient solution or to the soil. Manganese deficiency in soybean leaves was reported in Brazil when high lime rates were applied, resulting in soil pH over 6.0 and leaf Mn below $13 \mathrm{~g} \mathrm{~kg}^{-1}$ (Tanaka et al., 1992), but in the present experiment leaf Mn always exceeded the threshold level, according to Malavolta et al. (1997). In field experiments in Brazil, GR soybean cultivars showed glyphosate toxicity and received extra Mn sprayed to leaves, with no significant response (Broch \& Ranno, 2008; Stefanello et al., 2009). Therefore, there is no indication that soybean $\mathrm{Mn}$ requirements are different in GR and non-GR soybean cultivars and that fertilization programs should be modified for GR cultivars. 
Soybean Mn absorption, accumulation and resistance to $\mathrm{Mn}$ are under genetic controll and there is considerable variance among cultivars. The genes that control these traits are likely to be additive with little or no dominance (Rosolem, 1989). This is one of the reasons explaining the diverse effects obtained when studying soybean Mn nutrition. Other factors, such as the activity of microorganisms responsible for Mn dynamics in the soil (Kremer \& Means, 2009) could influence the availability of nutrients to plants and could have been affected by glyphosate (Kremer et al., 2005), eventually interfering with Mn availability and uptake by soybean, although this was not observed in the present experiment. After glyphosate application some leaf yellowing was also observed for a few days, although the symptom did not persist in new growth. A uniform yellowing started on the leaf edges progressing towards the main vein. Although this symptom is different from $\mathrm{Mn}$ deficiency symptoms, it may be misinterpreted in the field, at some point of the symptom development.

The extent of injury in glyphosate-treated GR soybean has been correlated with levels of aminomethylphosphonic acid (AMPA) formed within the plant (Reddy et al., 2004; Zablotowicz \& Reddy, 2007). This metabolite can lead to reduced photosynthetic rate, stomatal conductance and transpiration rate (Zobiole et al., 2010) and eventually affect mineral uptake. It was hypothesized that the enzymatic conversion of glyphosate to AMPA in GR soybean would require a certain level of external Mn supply (Bott et al., 2008), which was insufficient in the 0.1 , but enough in the $0.5 \mu \mathrm{g} \mathrm{L}^{-1} \mathrm{Mn}$ solution concentration in the cited experiment. However, this does not seem to be the case, as shown in our experiment with much higher Mn solution levels. Thus, if there is any effect of glyphosate on soybean Mn nutrition it must be indirect, secondary and strongly dependent on the soybean cultivar, development stage, physiological conditions, and growth environment.

\section{CONCLUSIONS}

The results experiments conducted unde controlled conditions, does not support the reported deleterious effect of glyphosate application on Mn absorption, accumulation and distribution in plants of glyphosateresistant soybean genotypes. Thus, it can be inferred that the introduction of the GR gene does not lead to significant changes in soybean response to $\mathrm{Mn}$. However, plants sprayed with glyphosate show a temporary phytotoxicity characterized as leaf yellowing. This symptom may, under field conditions, be misinterpreted as Mn deficiency.

\section{ACKNOWLEDGEMENTS}

This research was funded by FAPESP (The State of São Paulo Research Foundation).

\section{LITERATURE CITED}

AMARANTE Jr., O.P.; SANTOS, T.C.R.; BRITO, N.M. \& RIBEIRO, M.L. Glifosato: Propriedades, toxicidade, usos e legislação. Química Nova, 25:589-593, 2002.

BOTT, S.; TESFAMARIAM, T.; CANDAN, H.; CAKMAK, I.; RÖMHELD, V. \& NEUMANN, G. Glyphosate-induced impairment of plant growth and micronutrient status in glyphosate-resistant soybean. Plant Soil, 312:185-194, 2008.

BROCH, D.L. \& RANNO, S.K. Fertilidade do solo, adubação e nutrição da cultura da soja. In: Tecnologia de produção de soja e milho 2008/2009. Maracajú, Fundação MS, 2008. p.5-36.

CLAASSEN, N. \& BARBER, S.A. A method for characterizing the relation between nutrient concentration and flux into roots of intact plants. Plant Physiol., 54:564-568, 1974.

COLE, D.J. Mode of action of glyphosate - a literature analysis. In: GROSSBARD, E. \& ATKINSON, D., eds. The herbicide glyphosate. London, Butterworths, 1985. p.48-74.

EPSTEIN, E. \& HAGEN, C.E. A kinetic study of the absorption of alkali cations by barley roots. Plant Physiol., 27:457474, 1952 .

GORDON, B. Manganese nutrition of glyphosate-resistant and conventional soybean. Better Crops, 4:12-13, 2007.

HOAGLAND, R.E. Effects of glyphosate on metabolism of phenolic compounds: VI. Effects of glyphosine and glyphosate metabolites on phenylalanine ammonia-lyase activity, growth and protein, chlorophyll, and anthocyanin levels in soybean seedlings. Weed Sci., 28:393-400, 1980.

KREMER, R.J. \& MEANS, N.E. Glyphosate and glyphosateresistant crop interactions with rhizosphere microorganisms. Europ. J. Agron., 31:153-161, 2009.

KREMER, R.J.; MEANS, N.E. \& KIM, S. Glyphosate affects soybean root exudation and rhizosphere microorganisms. Intern. J. Anal. Chem., 85:1165-1174. 2005.

MALAVOLTA, E.; CABRAL, C.P. \& LAVRES Jr., O.A.J. Efeitos do manganês sobre a soja cultivada em solo de cerrado do triângulo mineiro. Pesq. Agropec. Bras., 35:1629-1636, 2000.

MALAVOLTA, E.; VITTI, G.C. \& OLIVEIRA, A.S. Avaliação do estado nutricional das plantas: Princípios e aplicações. 2.ed. Piracicaba, Potafos, 1997. 319p.

MARSCHNER, H. Mineral nutrition of higher plants. 2.ed. London, Academic Press, 1995. p.347-364. 
OZTURK, L.; YAZICI, A.; EKER, S.; GOKMEN, O.; ROEMHELD, V. \& CAKMAk, I. Glyphosate inhibition of ferric reductase activity in iron deficient sunflower roots. New Phytol., 17:899-906, 2008.

STEFANELLO, F.F.; MARCHETTI, M.E.; SILVA, E.F.; NOVELINO, J.O.; DORETO, R.B.S.; STEFANELLO, J. \& SERRA, A.P. Aplicação de glifosato em soja transgênica e seu efeito na absorção de manganês. In: CONGRESSO BRASILEIRO DE CIÊNCIA DO SOLO, 32., Fortaleza, 2009. Anais. Fortaleza, Sociedade Brasileira de Ciência do Solo, 2009. CD ROM.

REDDY, K.N.; DUKE, S.O. \& RIMANDO, A.M. Aminomethylphosphonic acid, a metabolite of glyphosate, causes injury in glyphosate-treated, glyphosate-resistant soybean. J. Agric. Food Chem., 52:5139-5143, 2004.

RICORDI, H.A.; TORNISIELO, L.V. \& ALMEIDA, D.P.G. Translocação de ${ }^{14} \mathrm{C}$ - glifosato entre Brachiaria brizantha e mudas de café (Coffea arábica) e citros (Citrus limonia Osbeck). In: SIMPÓSIO INTERNACIONAL SOBRE GLYPHOSATE, 2007, Botucatu. Anais. Botucatu, Universidade Estadual Paulista, 2007. p.307-310.

RÖMHELD, V.; GULDNER, G.; YAMADA, T.; OZTURK, L.; CAKMAK, I. \& NEUMANN, G. Relevance of glyphosate in the rhizosphere of non-target plants in orchards for plant health. In: LI, C.J.; ZHANG, F.S.; DOBERAMNN, A.; HINSINGER, P.; LAMBERS, H.; LI, X.L.; MARSCHNER, P.; MAENE, L.; McGRATH, S.; OENEMA, O.; PENG. S.B.; RENGEL. Z.;SHEN, Q.R.;WELCH, R.; von WIREN, N.; YAN, X.L. \& ZHU, Y.G., eds. Plant Nutrition for food security, human health and environment protection. Beijing, Tsinghua University Press, 2005. p.476-477.
ROSOLEM, C.A. Manganese toxicity in soybean. In: WORLD SOYBEAN RESEARCH CONFERENCE, 1989, Buenos Aires. Proceedings... Buenos Aires, Associación Argentina de La Soja, 1989. v.1. p.225-231.

ROSOLEM, C.A.; MIYAZAWA, M.; FRANCHINI, J.C.; PAVAN, M.A. \& COSTA, A. Soil acidity, $\mathrm{pH}$ and aluminium management in tropical soils: The Brazilian experience. In: WORLD SOYBEAN RESEARCH CONFERENCE, 7., 2004, Foz do Iguaçu. Proceedings....Foz do Iguaçu, Embrapa, 2004. p.310-318.

SCHULZ, A.; MUNDER, T.; HOLLAENDER-CZYTKO, H. \& AMRHEIN, N. Glyphosate transport and early effects on shikimate metabolism and its compartmentation in sink leaves of tomato and spinach plants. Zeitsch. Naturforsch., 45:529-534, 1990.

TANAKA, R.T.; MASCARENHAS, H.A.A. \& BULISANI, E.A. Deficiência de manganês em soja induzida por excesso de calcário. Pesq. Agropec. Bras., 27:247-250, 1992.

WONG, P.K. Effects of 2,4-D glyfosate and paraquat on growth, photosynthetic and chlorophyll-a synthesis of Scenedesmus quadricauda, Berb 614. Chemosphere, 41:177-182, 2002.

ZOBIOLE, L.H.S.; OLIVEIRA JR., R.S.; HUBER, D.M.; CONSTANTIN, J.; CASTRO, C.; OLIVEIRA, F.A. \& OLIVEIRA JR., A. Glyphosate reduces shoot concentrations of mineral nutrients in glyphosateresistant soybean. Plant Soil, 328:57-69, 2010.

ZABLOTOWICZ, R.M. \& REDDY, K.N. Nitrogenase activity, nitrogen content, and yield responses to glyphosate in glyphosate-resistant soybean. Crop Protec., 26:370-376, 2007. 